\title{
Aplikasi Pemberitahuan Penggaajian dan Pemberian Rekomendasi Pinjaman dengan Metode SAW (Studi Kasus: Rutan Klas 1 Bandung)
}

\author{
Nisa Hanum Harani ${ }^{1}$, Woro Isti Rahayu ${ }^{2}$, Farhan Maulana ${ }^{3}$ \\ Program Studi Teknik Informatika, Poltieknik Pos Indonesia, Bandung, Indonesia ${ }^{1,2,3}$ \\ e-mail: nisahanum@poltekpos.ac.id ${ }^{1}$,woroisti@poltekpos.ac.id ${ }^{2}$, farhanmaulana88@gmail.com ${ }^{3}$
}

\begin{abstract}
Abstrak
Perkembangan teknologi yang semakin maju membuat beberapa hal mulai ada campur tangan teknologi. Tidak bisa dipungkiri bahwa pada saat ini apapun harus berhubungan dengan teknologi karena efektif dan efisien. Salah satunya adalah proses penyebaran informasi yang sudah menggunakan internet untuk mempermudah kegiatan penyebaran tersebut. Pada salah satu instansi negara yaitu Rutan Klas 1 Bandung khususnya bagian keuangan, penyebaran informasi sangat dibutuhkan terutama pemberitahuan gaji melalui slip gaji yang masih manual dan menghabiskan penggunaan kertas serta tinta. Selain itu salah satu masalah lain adalah pemberian pinjaman pada pegawai yang tekadang angsuran pembayaran setiap bulan lebih besar dari gaji yang diterima, hal ini kurang telitinya pegawai keuangan dalam merekomendasikan daftar pinjaman. Untuk menyelesaikan masalah tersebut maka pembuatan aplikasi pengiriman slip gaji melalui email dan penerapan metode SAW (Simple Additive Weighting) pada pemberian rekomendasi terbaik untuk memilih pinjaman yang akan menghindarkan data dari human error. Maka setelah melakukan pengujian terhadap aplikasi, penyebaran informasi penggajian melalui email berjalan baik dan metode SAW yang digunakan pun memberikan rekomendasi terbaik dan menghilangkan data pinjaman yang tidak mungkin dipinjam oleh pegawai tersebut.
\end{abstract}

Kata Kunci : Slip Gaji, Pengiriman Email, Pinjaman, Rekomendasi, SAW

\begin{abstract}
The development of increasingly advanced technology has made several things begin to interfere with technology. It is undeniable that at present anything must be related to technology because it is effective and efficient. One of them is the process of disseminating information that is already using the internet to facilitate the dissemination activities. In one of the state agencies, namely Rutan Klas 1 Bandung, especially the finance department, the dissemination of information is needed, especially salary notifications through salary slips which are still manual and consumes paper and ink. In addition, one of the other problems is the provision of loans to employees who sometimes have monthly payment installments greater than the salary received, this is the lack of careful financial staff in recommending a list of loans. To solve this problem, making an application for sending pay slips via e-mail and applying the SAW (Simple Additive Weighting) method to provide the best recommendations for choosing a loan that avoids human error data. So after testing the application, payroll information dissemination via e-mail works well and the SAW method used also provides the best recommendations and eliminates loan data that is impossible for the employee to borrow.
\end{abstract}

Kata Kunci : Salary Slip, Email Delivery, Loans, Recommendations, SAW

\section{Pendahuluan}

Pada zaman era globalisasi ini informasi sangatlah penting bagi sebuah perusahaan. Informasi dari satu bagian saling terkait dengan bagian lainya [1]. Karena pada 
umumnya seluruh kegiatan menggunakan komputer terutama di perkantoran[2]. Ini ditandai dengan penerapan sistem layanan yang telah terkomputerisasi di berbagai lembaga dan berbagai bidang untuk memberikan kemudahan bagi perusahaan dan bagi pengguna untuk menemukan informasi dengan cepat dan akurat. Salah satu sistem yang banyak digunakan dalam suatu perusahaan untuk mengoptimalkan kualitas layanan mereka adalah penerapan daftar gaji sistem informasi[3]. Adapun sebenarnya sistem penggajian yang sering diterapkan sekarang ini terkadang masih menemui banyak masalah, diantaranya kesulitan dalam proses pembuatan slip gaji karyawan karena masih belum terkomputerisasi[4]. Jika hal ini masih ditangani dengan cara yang konvensional atau manual maka karyawan akan terlambat menerima slip gaji mereka[5].

Mengingat sekarang memang sangat dibutuhkannya peran sistem penggajian, maka sistem tersebut harus didesain secara baik agar dapat membantu memberikan informasi kepada pihak manajemen dalam hal pengambilan keputusan, selain itu juga dapat berupa informasi berkualitas yang disajikan dalam bentuk laporan[6]. Selain penggajian tentu juga masalah pada hal pengelolaan peminjaman uang dari pegawai sebuah perusahaan kepada bank yang apabila pengelolaan tersebut dilakukan secara manual tentu terlalu riskan. Halhal kecil saja seperti dalam penginputan data peminjaman nasabah serta dalam pengolahan data yang masih menggunakan Microsoft word dan Microsoft excel[7]. Dengan metode SAW yang digunakan sebagai pembantu pegawai dalam mengambil keputusan, tentu hasil yang didapat adalah berdasar dari beberapa kriteria yang berhubungan.

Pada salah satu instansi negara yaitu Rumah Tahanan Negara Klas 1 Bandung, pengelolaan alur pinjaman masih bersifat manual dan pemberitahuan slip gaji pegawai masih berbentuk fisik. Dengan demikian kemungkinan human error dalam pengelolaan pinjaman cukup tinggi dan juga setiap bulan divisi keuangan harus selalu melakukan pencetakan terhadap data tersebut yang sebenarnya tidak semua pegawai dan mungkin hanya sekitar 20 dari 190 orang akan mengambil slip gaji tersebut.

Oleh karena itu untuk mengatasi hal tersebut dibuatlah sebuah sebuah system yang akan mengelola kemudian memberikan alternatif terbaik dalam hal pinjaman terhadap bank dan juga akan memudahkan karyawan untuk melihat slip gaji tanpa harus berada dikantor, karena karyawan dapat mengakses email dimanapun berada[8]. Dengan dibuatnya system ini, diharapkan resiko human error yang dapat menjadi fatal dalam hal pengelolaan pinjaman pada bank dapat di kurangi karena kemudahan menampilkan dan mengelola data secara cepat dan akurat, selanjutnya adalah permasalahan pada slip gaji yang masih harus selalu di cetak setiap bulan sudah tidak perlu lagi, dan juga mengurangi penggunaan kertas karena data tersebut sudah dikirimkan melalui email masing-masing.

\subsection{Penggajian}

\section{Kajian Pustaka}

Gaji atau upah adalah hak pekerja yang diterima dalam bentuk uang sebagai imbalan dari hasil kerja yang diberikan pemberi kerja kepada pekerja dan dibayar menurut suatu perjanjian kerja, kesepakatan, atau peraturan dari perundang-undangan, termasuk juga tunjangan untuk para pekerja dan tentu keluarganya atas pekerjaan yang akan atau telah dilakukan[1].

\subsection{Sistem Rekomendasi}

Sistem rekomendasi adalah suatu sistem yang menyarankan informasi yang berguna atau menduga apa yang akan dilakukan pelanggan untuk mencapai tujuannya, misalnya seperti memilih produk tertentu. Sehingga pelanggan memilih produk dapat lebih efektif dalam menentukan produk yang diinginkannya[9]. 


\subsection{Email}

Email adalah Electronic mail (Surat elektronik), merupakan metode surat menyurat dari menulis, mengirim, menerima dan menyimpan surat melalui sebuah sistem komunikasi elektronik[10]. Email biasa digunakan sebagai sarana komunikasi formal antara individu ke perusahaan atau perusahaan ke perusahaan.

\section{$2.4 \quad$ Kredit}

Kredit memiliki arti menyediakan uang atau juga tagihan yang dapat disama artikan dengan itu, berdasarkan dari kesepakatan pinjam dan meminjam yang dilakukan antara bank dengan pihak lainnya yang mengharuskan pihak dari peminjam dapat melunasi utangnya setelah jangka waktu tertentu dengan adanya bunga (UU No. 10 tahun 1998) [11]. Kredit juga bisa diartikan sebagai kemampuan untuk melakukan suatu pembelian atau mengadakan suatu pinjaman dengan janji bahwa pembayarannya tersebut akan dilakukan pada suatu jangka waktu tertentu yang sebelumnya telah disepakati bersama[12].

\section{$2.5 \quad$ Hypertext Preprocessor (PHP)}

Hypertext Preprocessor (PHP) adalah sebuah bahasa pemrograman yang berbentuk scripting, system kerja dari program ini adalah sebagai interpreter bukan compiler. Hal ini memiliki arti bahwa semua sintaks yang diberikan akan seluruhnya dijalankan di server sedangkan untuk yang dikirim ke browser hanya hasil saja. Ketika salah satu pengguna internet membuka website yang sudah menggunakan fasilitas serverside scripting PHP, maka server yang bersangkutan akan melakukan proses dari semua perintah PHP di server terlebih dahulu kemudian mengirimkan hasil tersebut dalam format HTML ke web server pengguna dari internet sebelumnya. Sehingga kode sebenarnya yang telah ditulis menggunakan PHP tidak akan terlihat di browser pengguna. PHP tergolong sebagai perangkat lunak opensource yang diatur dalam dalam aturan General Purpose Licences (GPL). Pemograman PHP sangat bagus dikembangkan didalam lingkungan web, karena PHP dapat dilekatkan didalam script HTML atau juga sebaliknya. PHP dikhususkan untuk pengembanga web dinamis. Maksudnya, PHP mampu menghasilkan website yang secara terusmenerus hasilnya bisa berubah-ubah sesuai dengan pola yang diberikan[13].

2.6 Simple Additive Weighting

Metode SAW biasa dikenal juga dengan istilah metode dengan penjumlahan yang terbobot. Konsep dasar dari metode SAW ini sebenarnya mencari penjumlahan yang terbobot dari nilai kinerja pada masing-masing alternatif di semua atribut. Metode ini harus ada proses dari normalisasi pada matriks keputusan (X) ke suatu skala sebagai pembanding dengan semua nilai alternatif yang ada [14].

Formula yang digunakan untuk melakukan normalisasi adalah seperti pada persamaan 1 .

$$
R i j\left\{\begin{array}{l}
\frac{X_{i j}}{\operatorname{Max} X_{i j}} \text { jika jadalahatribut keuntungan(benefit) } \\
\frac{\operatorname{Min} X_{i j}}{X_{i j}} \text { jika jadalahatribut pengeluaran }(\text { cost })
\end{array}\right.
$$

Keterangan:

Rij = Nilai kinerja yang sudah dinormalisasi dari alternatif Ai pada atribut

$$
\mathrm{Cj}: \mathrm{i}=1,2, \ldots, \mathrm{m} \text { dan } \mathrm{j}=1,2, \ldots, \mathrm{n}
$$

$\operatorname{Max} \mathrm{Xij}=$ Nilai terbesar dari setiap kriteria $\mathrm{i}$

Min Xij $\quad=$ Nilai terkecil dari setiap kriteria $\mathrm{i}$

$\mathrm{Xij}=$ Nilai atribut yang dimiliki dari setiap kriteria 
Benefit $\quad=$ Jika nilai terbesar adalah terbaik

Cost $\quad=$ Jika nilai terkecil adalah terbaik

Nilai untuk setiap alternatif akan diberikan rumus seperti pada persamaan 2:

$$
V i=\sum_{j=1}^{n} W_{j} r_{i j}
$$

Keterangan:

$\mathrm{Vi} \quad=$ Rangking untuk setiap alternatif

$\mathrm{Wj} \quad=$ Nilai bobot rangking (dari setiap alternatif)

rij = Nilai rating kinerja ternormalisasi

Nilai dengan perhitungan yang lebih besar dibanding yang lain akan mengindikasikan alternatif tersebut lebih terpilih yaitu alternatif.

\section{Metode Penelitian}

Pada penelitian ini akan diterapkan algoritma Simple Additive Weighting (SAW) pada proses pemberian rekomendasi pinjaman pada bank BJB untuk pegawai Rumah Tahanan Klas 1 Bandung. Untuk menyelesaikan penerapan tersebut dibutuhkan suatu metodologi penelitian yang meliputi beberapa tahapan yaitu perumusan masalah, analisis solusi program, penentuan batasan, pengumpulan data (wawancara, observasi), perancangan program, implementasi simple additive weighting (analisa hasil, rekomendasi), pengujian sistem, kesimpulan, dan saran. 


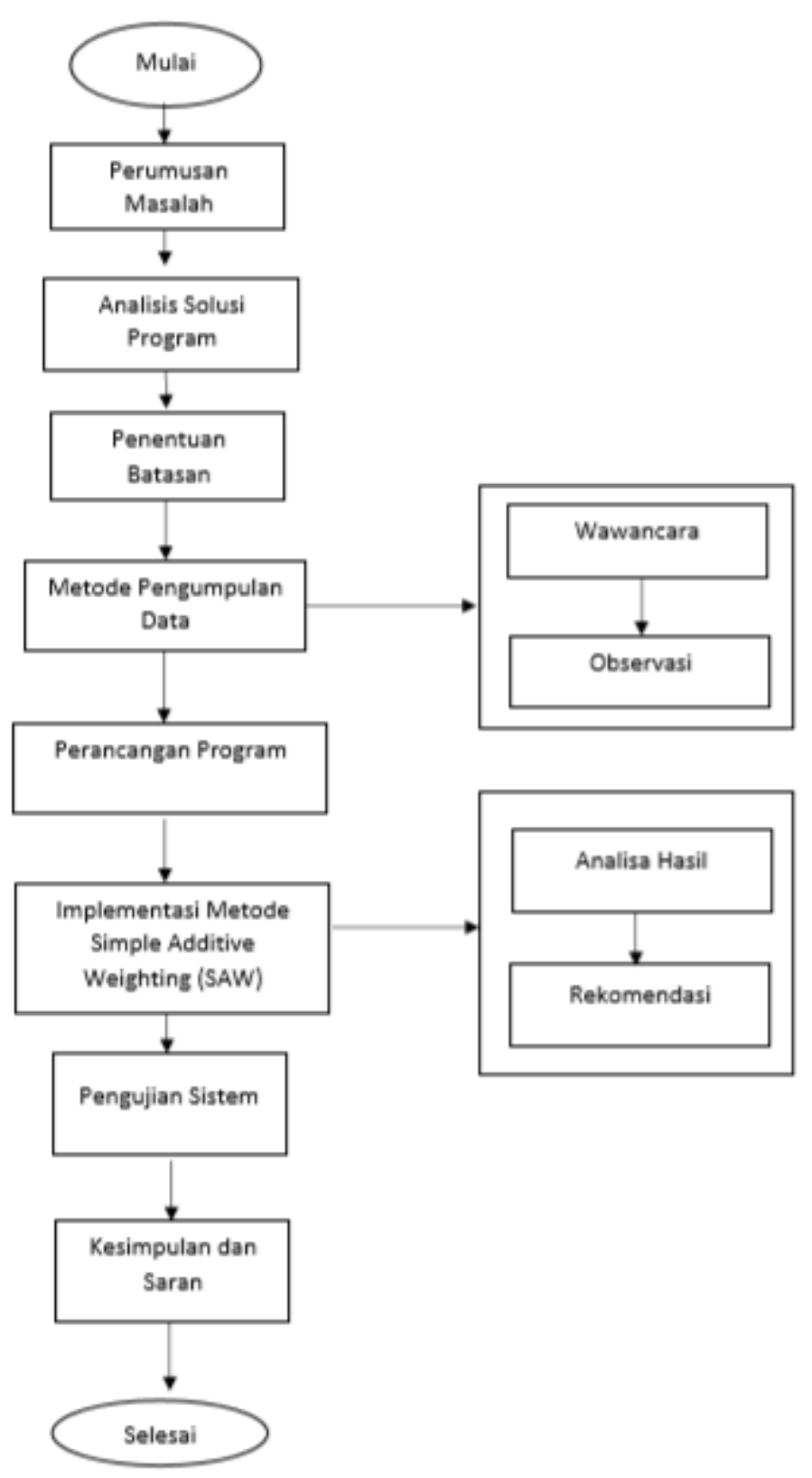

Gambar 1. Alur Metodologi Penelitian

\subsection{Tahapan-Tahapan Diagram Alur Penelitian}

Berikut adalah tahapan tahapan berdasarkan pada diagram alur metodologi penelitian pada gambar 1 .

\subsubsection{Identifikasi dan Perumusan Masalah}

Tahap ini penulis mencoba mengidentifikasi apa masalah yang timbul dari sistem atau prosedur yang sudah berjalan saat ini, sehingga bisa dirumuskan untuk dibuatkan suatu sistem baru.

\subsubsection{Analisis Solusi Program}


Setelah mendapatkan rumusan masalah, maka menganalisis apa saja yang dibutuhkan dalam sebuah program tersebut. Hasil analisis tersebut harus juga menjawab masalah yang telah dirumuskan sebelumnya.

\subsubsection{Penentuan Batasan}

Tahap ini penting agar tidak terjadi kesalahpahaman antara penulis dan pembaca. Berisi point yang menerangkan bahwa aplikasi ini mencakup apa saja.

\subsubsection{Teknik Pengumpulan Data}

Teknik pengumpulan data merupakan langkah yang paling strategis dalam penelitian, karena tujuan utama dari penelitian adalah mengumpulkan data. Teknik pengumpulan data bisa dilakukan dengan beberapa cara seperti :

\section{Wawancara}

Wawancara adalah pertemuan dari dua orang untuk saling bertukar informasi dengan cara tanya jawab, sehingga dapat disimpulkan makna dalam suatu obrolan tertentu. Dalam wawancara terhadap beberapa pegawai Rumah Tahanan Negara Klas 1 Bandung ini didapat data dan alur mengenai penggajian dan peminjaman yang dibutuhkan kemudian yang akan menjadi landasan utama dari dibentuknya beberapa nilai dari kriteria-kriteria yang nanti akan dimasukan.

2. Pengamatan/Observasi

Observasi adalah suatu proses yang cukup rumit, proses yang tersusun dari banyak proses biologis serta psikologis. Dua proses terpenting adalahproses pengamatan dan ingatan. Dari hasil pengamatan secara langsung dari kegiatan pendataan penggajian dan peminjaman didapat beberapa data yang akan melengkapi hasil wawancara karena kegiatan langsung dilapangan akan lebih meyakinkan dan menjadi suatu bukti dari alur atau data yang didapat dari wawancara sebelumnya.

\subsubsection{Perancangan Program}

Di tahap ini, penulis merancang dan membuat aplikasi sesuai dengan hasil kebutuhan dan keinginan pengguna, menggunakan bahasa PHP dan JavaScript, framework Laravel, akan berjalan di platform website dan pemecahan masalah menggunakan metode Simple Additive Weighting.

\subsubsection{Implementasi Simple Additive Weighting}

Pada tahap implementasi ini merupakan bagian penerapan pengembangan system dan juga penerapan metode penyelesaian masalah berdasarkan perancangan yang telah dibuat sebelumnya.

1. Analisa Hasil

Akan didapatkan beberapa hasil dari alternatif yang sebelumnya sudah diajukan. Maka akan disusun berdasarkan hasil dari yang direkomendasikan sampai yang tidak direkomendasikan.

2. Rekomendasi

Setelah rekomendasi disusun menjadi daftar yang akan menjadi pilihan dari hasil pinjaman, selanjutnya diserahkan ke masing-masing pegawai dari Rumah Tahanan Klas 1 Bandung sebagai bahan pertimbangan yang lebih baik dalam melakukan pinjaman dari hasil data yang pada langkah sebelumnya yang sudah didapat. 


\subsubsection{Pengujian Sistem}

Pada tahap pengujian sistem ini bertujuan untuk mencari kesalahan dalam sistem, termasuk juga pengecekan apakah kebutuhan dan keinginan pelanggan sebenarnya telah terpenuhi atau belum, jika terdapat ketidak sesuaian maka sistem tersebut belum layak untuk digunakan dan diperlukan perbaikan. Apabila dalam pengujian tersebut sudah sesuai dengan kebutuhan maka sistem tersebut sudah siap untuk digunakan.

\subsubsection{Kesimpulan dan Saran}

Pada tahap ini merupakan proses terakhir dalam melakukan penelitian. Penulis akan menyimpulkan secara keseluruhan dari hasil penelitian yang telah dilakukan serta memberikan beberapa saran untuk pembaca.

\subsection{Pengkajian}

\section{Hasil dan Pembahasan}

Dalam pengkajian ini, penulis akan mengkaji kembali data yang telah diperoleh dari hasil pengumpulan data yang dilakukan sebelumnya untuk mendukung analisis penelitian ini, untuk memberikan solusi kepada pegawai rekomendasi pinjaman yang paling baik dengan gaji yang mereka miliki.

\subsection{Identifikasi Masalah}

Pada identifikasi masalah yang telah dipaparkan sebelumnya, yaitu untuk penyebaran informasi penggajian yang masih manual kemudian akan diselesaikan dengan menggunakan email dan pemberian rekomendasi pinjaman yang akan diselesaikan menggunakan metode SAW. Tujuan penelitian ini adalah memudahkan proses pemberian informasi gaji dan memberikan nilai alternatif pada pemilihan pinjaman untuk mengetahui solusi dan penerapan dari metode SAW. Hasil pengiriman email gaji dan penerapan metode SAW dalam pemberian rekomendasi pinjaman Bank BJB menggunakan bahasa pemrograman PHP.

\subsection{Pengujian Pengiriman Email Gaji}

Pada tahap pengujian ini, dilakukan pengujian pada aplikasi untuk pengirimkan data penggajian melalui email menggunakan bahasa pemograman PHP.

\subsubsection{Penginputan Data Pegawai}

Gambar 2 adalah berisi proses penginputan data dari pegawai dan gambar 3 adalah daftar seluruh pegawai yang ada di dalam aplikasi. 


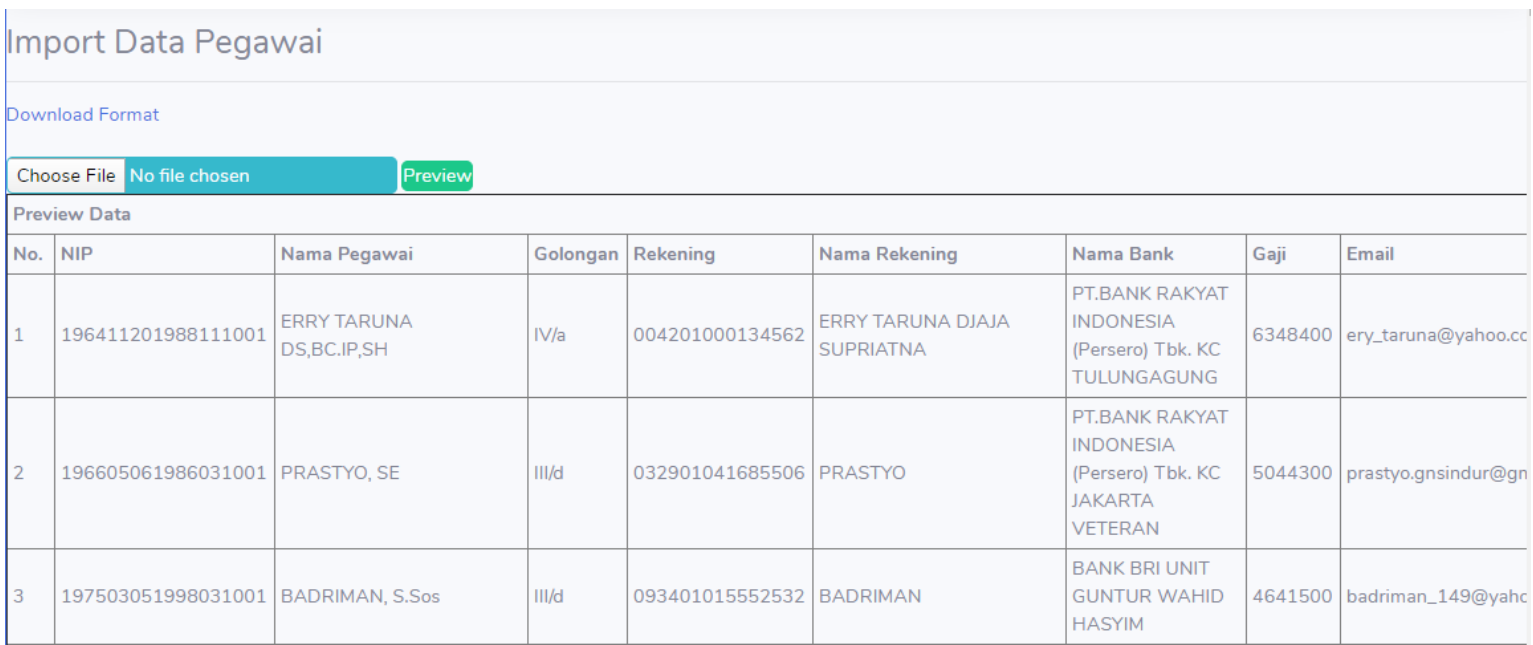

Gambar 2. Penginputan Data Pegawai

Daftar Tabel / Tabel Pegawai

Data Pegawai (Gaji Pokok)

\section{Delete All}

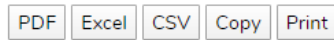

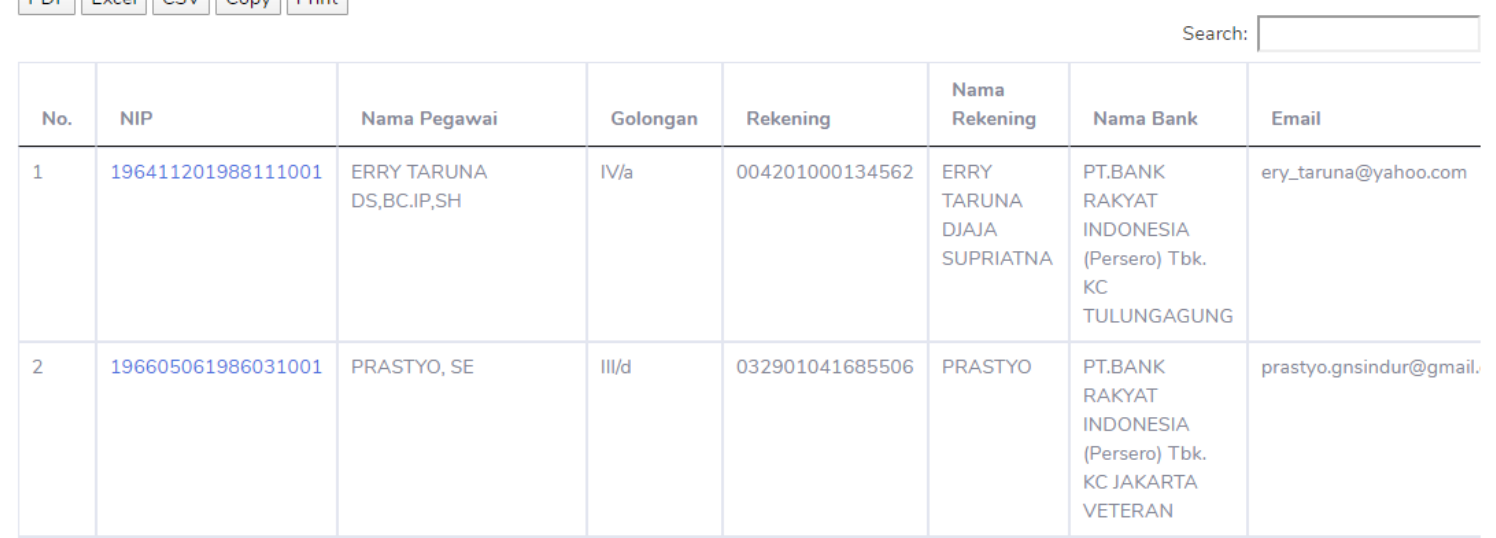

Gambar 3. Daftar Seluruh Pegawai Dalam aplikasi

\subsubsection{Penginputan Data Gaji Bulanan}

Gambar 4 adalah berisi proses penginputan data dari potongan gaji pegawai dan gambar 5 adalah daftar seluruh potongan gaji masing-masing pegawai yang ada di dalam aplikasi. 


\begin{tabular}{|c|c|c|c|c|c|c|c|c|c|c|c|}
\hline \multicolumn{12}{|l|}{ Download Format } \\
\hline Choose File No file chosen & \multicolumn{11}{|l|}{ Preview } \\
\hline \multicolumn{12}{|c|}{ Semua data belum diisi, Ada data yang belum diisi. } \\
\hline \multicolumn{12}{|c|}{ Preview Data } \\
\hline Nama & Bulan & Uang Makan & Tunker & $\mathrm{p} 1$ & p2 & p3 & $\mathrm{p} 4$ & p5 & $\mathrm{p} 6$ & p7 & $\mathrm{p} 8$ \\
\hline ERRY TARUNA DS,BC.IP,SH & May-20 & 871250 & 9896000 & 250000 & 50000 & & 370000 & & 150000 & 20000 & 15000 \\
\hline PRASTYO, SE & May-20 & 878750 & 3510400 & & 50000 & 460200 & 30000 & & 150000 & 20000 & 15000 \\
\hline BADRIMAN, S.SOS & May-20 & 878750 & 3510400 & & 50000 & 1963500 & 30000 & 57000 & 150000 & 20000 & 15000 \\
\hline SUYATNA, SH & May-20 & 913900 & 3510400 & & 50000 & & 30000 & & 150000 & 20000 & 15000 \\
\hline ARINTA AGUSTANA, SS & May-20 & 878750 & 5079200 & & 50000 & 1000000 & 150000 & & 150000 & 20000 & 15000 \\
\hline TRI MULYONO,AMd.IP.,S.Sos & May-20 & 878750 & 5079200 & 250000 & 50000 & & 150000 & & 150000 & 20000 & 15000 \\
\hline EDY WIJAYA, SH & May-20 & 878750 & 4595150 & 250000 & 50000 & & 2800000 & & 150000 & 20000 & 15000 \\
\hline TITI DARMIATI & May-20 & 878750 & 4595150 & & 50000 & 2066000 & 30000 & 160000 & 150000 & 20000 & 15000 \\
\hline
\end{tabular}

Gambar 4. Penginputan Data Gaji

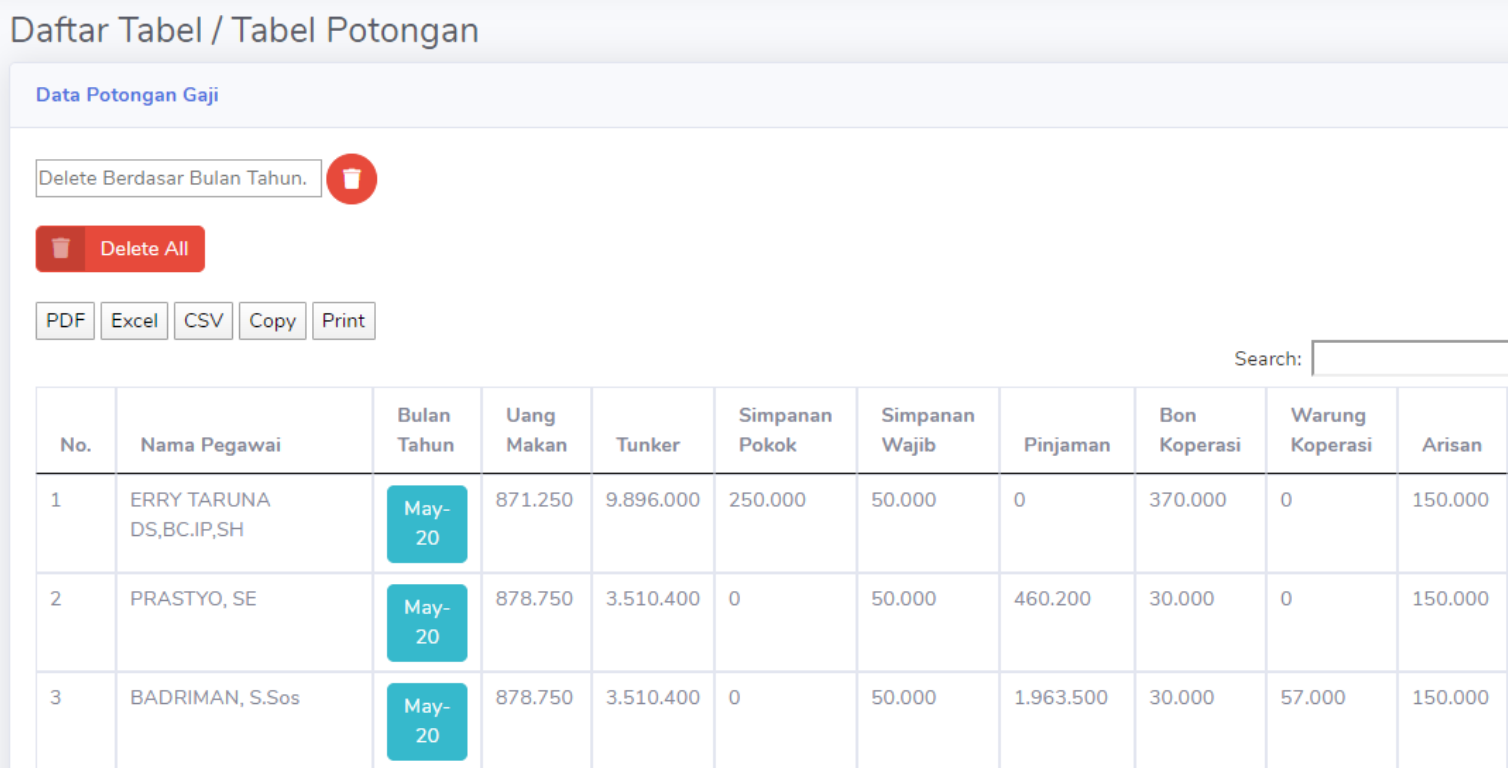

Gambar 5. Daftar Seluruh Potongan Gaji Pegawai Dalam aplikasi

\subsubsection{Tampilan Data Gaji Berdasarkan Bulan}

Hasil dari gambar 6 ini adalah daftar potongan gaji berdasarkan bulan tertentu yang datanya akan dikirimkan ke masing-masing email pegawai yang di pilih/ceklis. Sebagai contoh adalah akan dikirimnya gaji bulan mei 2020. Pada gambar 7 adalah tombol untuk mengirimkan data gaji yang sudah dipilih dan gambar 8 adalah hasil apabila email tersebut berhasil dikirimkan. 


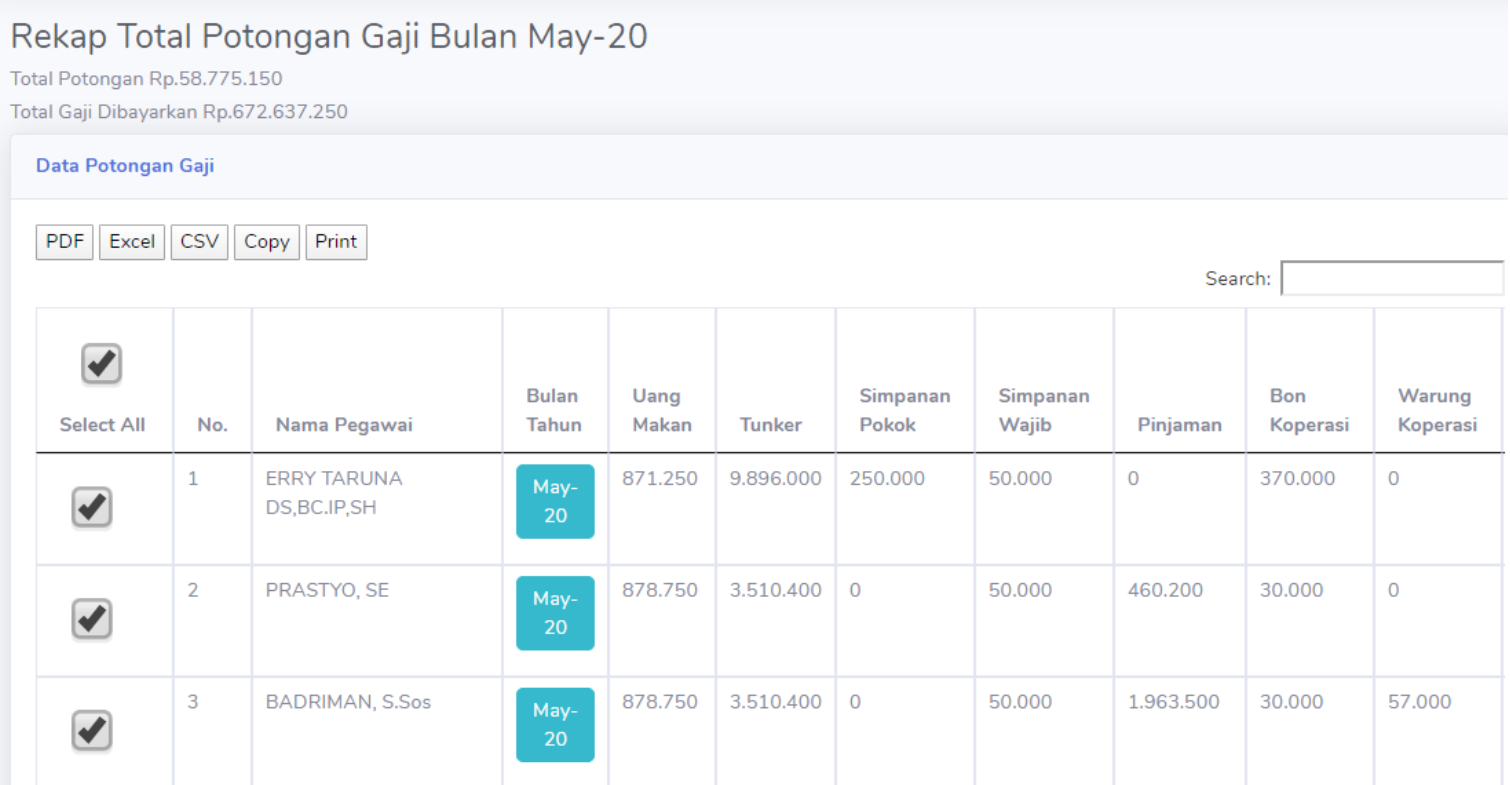

Gambar 6. Daftar Potongan Gaji Yang Akan Dikirimkan

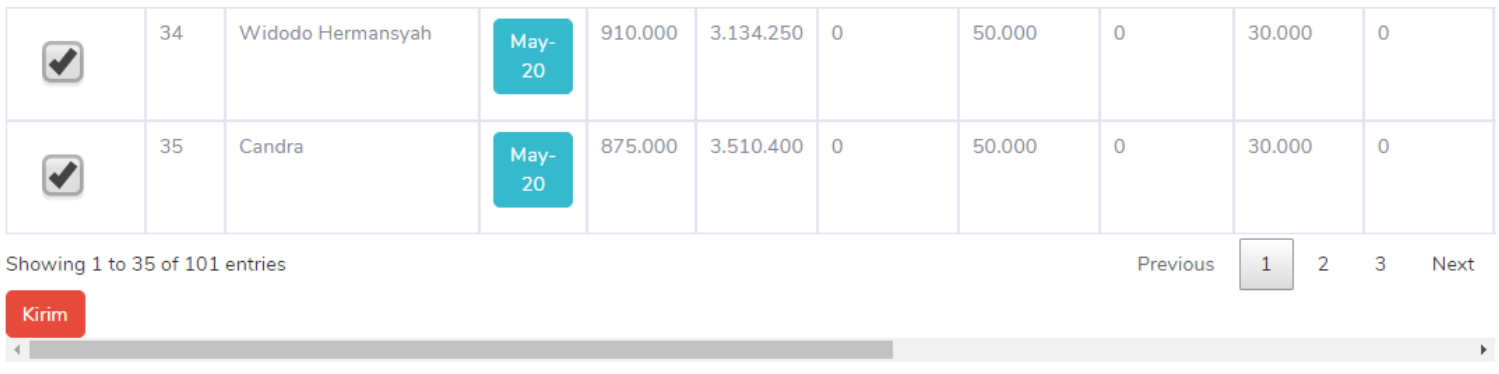

Gambar 7. Tombol Pengiriman Email

\section{localhost says}

Email Berhasil Dikirim!

Gambar 8. Pemberitahuan Pengiriman Berhasil

\subsubsection{Hasil Email Penggajian}

Hasil dari gambar 9 ini adalah isi email yang diterima oleh masing-masing pegawai. 


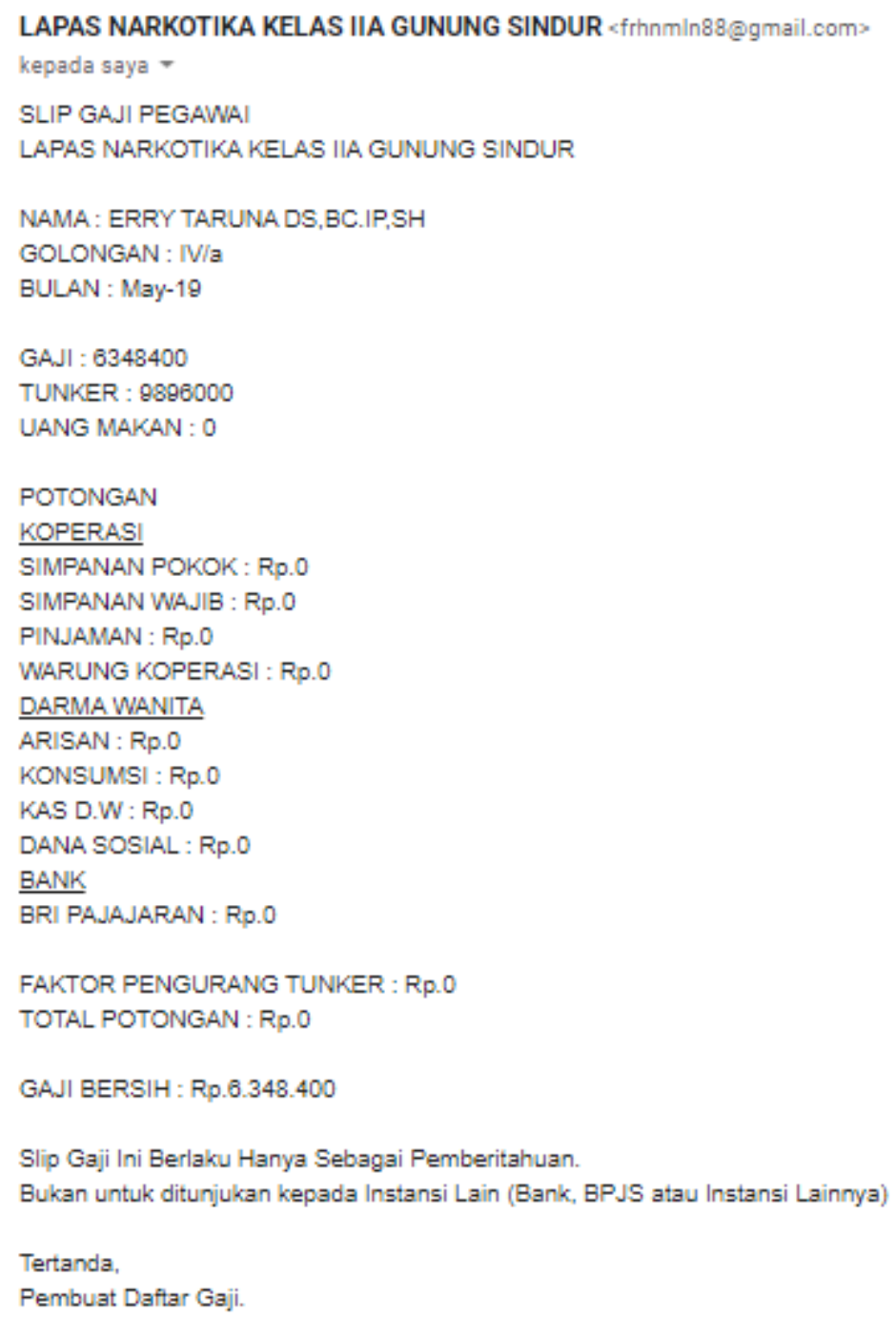

Gambar 9. Hasil Email Penggajian

\subsection{Pengolahan Data Menggunakan SAW (Manual)}

4.4.1 Pemilihan Data Pegawai

Perhitungan ini berawal dari pemilihan pegawai, perlu diketahui bahwa perhitungan ini juga berpatok pada jumlah gaji yang diterima karena masing-masing pegawai akan diberikan rekomendasi berbeda-beda sesuai dengan gaji yang diterimanya dan contoh untuk perhitungan yang diambil adalah seperti pada tabel 1 .

Tabel 1. Pemilihan Data Pegawai (Gaji Sebagai Patokan Angsuran)

\begin{tabular}{|c|c|}
\hline Pegawai & Gaji Diterima \\
\hline HERI KUSRITA, A.Md.IP.SH.MH & Rp. 4.780.800 \\
\hline
\end{tabular}

\subsubsection{Penentuan Bobot Kriteria}

Penentuan bobot ini dilakukan sebagai perhitungan beberapa kriteria yang telah ditentukan sebelumnya untuk mendapatkan hasil perhitungan yang nanti akan dikalikan 
dengan bobot yang ada pada tabel 2, penentuan bobot ini didapat dengan cara melakukan wawancara pada beberapa pegawai mengenai pendapatnya tentang pinjaman.

Tabel 2. Bobot Kriteria

\begin{tabular}{|c|c|}
\hline Kriteria & Bobot \\
\hline Plafond (C1) (benefit) & 0,6 \\
\hline Angsuran (C2) (cost) & 0,2 \\
\hline Lama Bulan (C3) (cost) & 0,2 \\
\hline
\end{tabular}

\subsubsection{Pemilihan Nilai Setiap Alternatif}

Dengan mengacu pada tabel 1 dan tabel 2, tabel 3 ini berisi 3 data yang dipilih dari seluruh data pinjaman yang ada. $\mathrm{C} 1$ adalah benefit maka diambil yang paling besar nilainya, kemudian $\mathrm{C} 2$ dan $\mathrm{C} 3$ adalah cost maka diambil yang paling sedikit nilainya.

Tabel 3. Nilai Setiap Alternatif

\begin{tabular}{|c|c|c|c|c|}
\hline No & Pinjaman & Plafond (C1) & Angsuran (C2) & Lama Bulan (C3) \\
\hline 1. & Pinjaman 1 & Rp. 100.000.000 & Rp. 4.707.347 & 24 \\
\hline 2. & Pinjaman 2 & Rp. 30.000.000 & Rp. 2.665.464 & 12 \\
\hline 3. & Pinjaman 3 & Rp. 10.000.000 & Rp. 120.017 & 180 \\
\hline
\end{tabular}

\subsubsection{Hasil Perhitungan Matrix Keputusan}

Hasil dari tabel 4 ini adalah perhitungan dari tabel 3 menggunakan persamaan 1.

Tabel 4. Matrix Keputusan

\begin{tabular}{|c|c|c|c|}
\hline Kriteria & C1 & C2 & C3 \\
\hline Bobot & 0,6 & 0,2 & 0,2 \\
\hline Pinjaman 1 & 1 & 0.0254956772891397 & 0,5 \\
\hline Pinjaman 2 & 0,3 & 0.0450266820335972 & 0,1 \\
\hline Pinjaman 3 & 0,1 & 1 & 0.0666666666666667 \\
\hline
\end{tabular}

\subsubsection{Hasil Perhitungan Matrix Ternormalisasi}

Hasil dari tabel 5 ini adalah perhitungan dari tabel 4 yang kemudian dikalikan dengan bobot kriteria pada tabel 2 sesuai dengan kriteria masing-masing nilai.

Tabel 5. Matrix Ternormalisasi

\begin{tabular}{|c|c|c|c|}
\hline Kriteria & C1 & C2 & C3 \\
\hline Pinjaman 1 & 0,6 & 0.0050991354578279 & 0,1 \\
\hline Pinjaman 2 & 0,1 & 0.0090053364067194 & 0,2 \\
& 8 & & 0.013333333333333 \\
\hline Pinjaman 3 & 0,06 & 0,2 & 3 \\
\hline
\end{tabular}

\subsubsection{Hasil Perhitungan Total Nilai Setiap Alternatif}


Hasil dari tabel 6 ini adalah penjumlahan masing-masing hasil perhitungan $\mathrm{C} 1, \mathrm{C} 2$, dan $\mathrm{C} 3$ pada tabel 5 kemudian didapatkan pengurutan hasil rekomendasi pinjaman untuk tabel 3 yang berurut dari pinjaman 1, pinjaman 2, dan terakhir pinjaman 3.

Tabel 6. Total Nilai Setiap Alternatif

\begin{tabular}{|c|c|c|}
\hline Alternatif & Nilai Total & Rank \\
\hline Pinjaman 1 & 0.70509913545783 & 1 \\
\hline Pinjaman 2 & 0.38900533640672 & 2 \\
\hline Pinjaman 3 & 0.273333333333333 & 3 \\
\hline
\end{tabular}

\subsection{Pengujian Metode SAW Pada Aplikasi}

Pada tahap pengujian metode ini, dilakukan pengujian metode untuk mengetahui apakah metode SAW dapat menghasilkan pemilihan alternatif terbaik untuk proses pemberian rekomendasi dengan proses pengolahan data menggunakan bahasa pemograman PHP yang akan dijelaskan oleh gambar 10 sampai gambar 14.

\subsubsection{Pemilihan Data Pegawai}

Gambar 10 adalah berisi pemilihan pegawai yang akan melakukan pinjaman dan sample nya sesuai dengan tabel 1 .

\begin{tabular}{|c|c|c|c|c|c|c|c|c|}
\hline No. & NIP & $\begin{array}{l}\text { Nama } \\
\text { Pegawai }\end{array}$ & Golongan & Rekening & $\begin{array}{l}\text { Nama } \\
\text { Rekening }\end{array}$ & $\begin{array}{l}\text { Nama } \\
\text { Bank }\end{array}$ & Email & Gaji Bersi \\
\hline 1 & $\underline{197501051998031001}$ & $\begin{array}{l}\text { HERI KUSRITA, } \\
\text { A.Md.IP.SH.MH }\end{array}$ & $\mathrm{IV} / \mathrm{a}$ & 0089596254100 & $\begin{array}{l}\text { HERI } \\
\text { KUSRITA }\end{array}$ & $\begin{array}{l}\text { BPD } \\
\text { JABAR } \\
\text { BANTEN }\end{array}$ & farhanmaulana88@gmail.com & Rp5.333.3 \\
\hline
\end{tabular}

Gambar 10. Pemilihan Data Pegawai

\subsubsection{Pengajuan Pinjaman Berdasarkan Gaji (Maksimal Angsuran)}

Gambar 11 adalah kelanjutan dari gambar 10 yang setelah memilih pegawai maka data penggajiannya akan ditampilkan berbentuk popup dan pada bagian gaji diterima, besaran itu akan menjadi patokan perhitungan dari rekomendasi pinjaman.

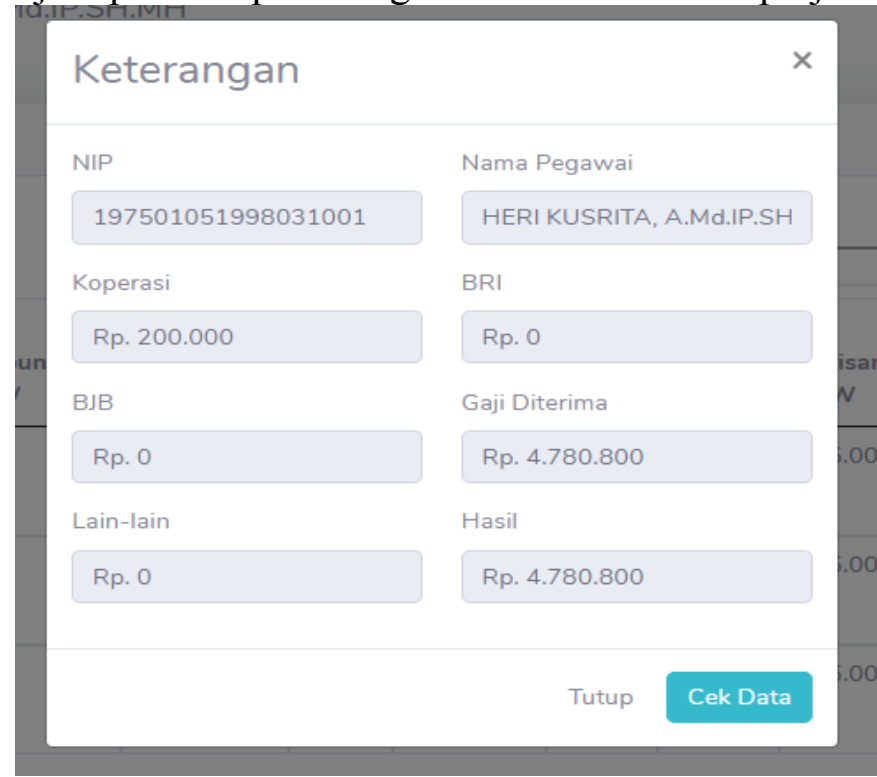

Gambar 11. Pengajuan Pinjaman Berdasarkan Gaji (Maksimal Angsuran)

\subsubsection{Matrix Keputusan}


Hasil dari gambar 12 ini adalah sama seperti pada tabel 4 yaitu didapat dari perhitungan data nomer 132, 31, dan 15 pada gambar 12 menggunakan persamaan 1 .

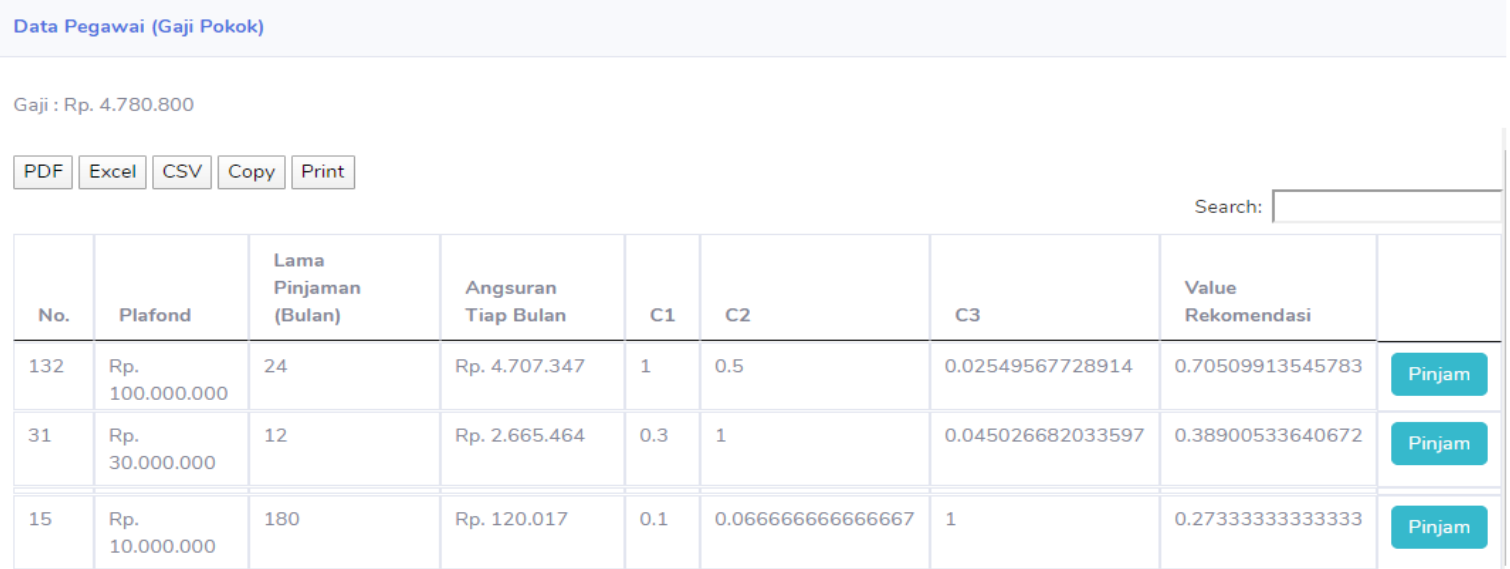

Gambar 12. Matrix Keputusan

\subsubsection{Matrix Ternormalisasi}

Hasil dari gambar 13 ini adalah perhitungan dari data nomer 132, 31, dan 15 pada gambar 13 yang kemudian dikalikan dengan bobot kriteria pada tabel 2 yang sudah dimasukan dalam program sesuai dengan kriteria masing-masing nilai.

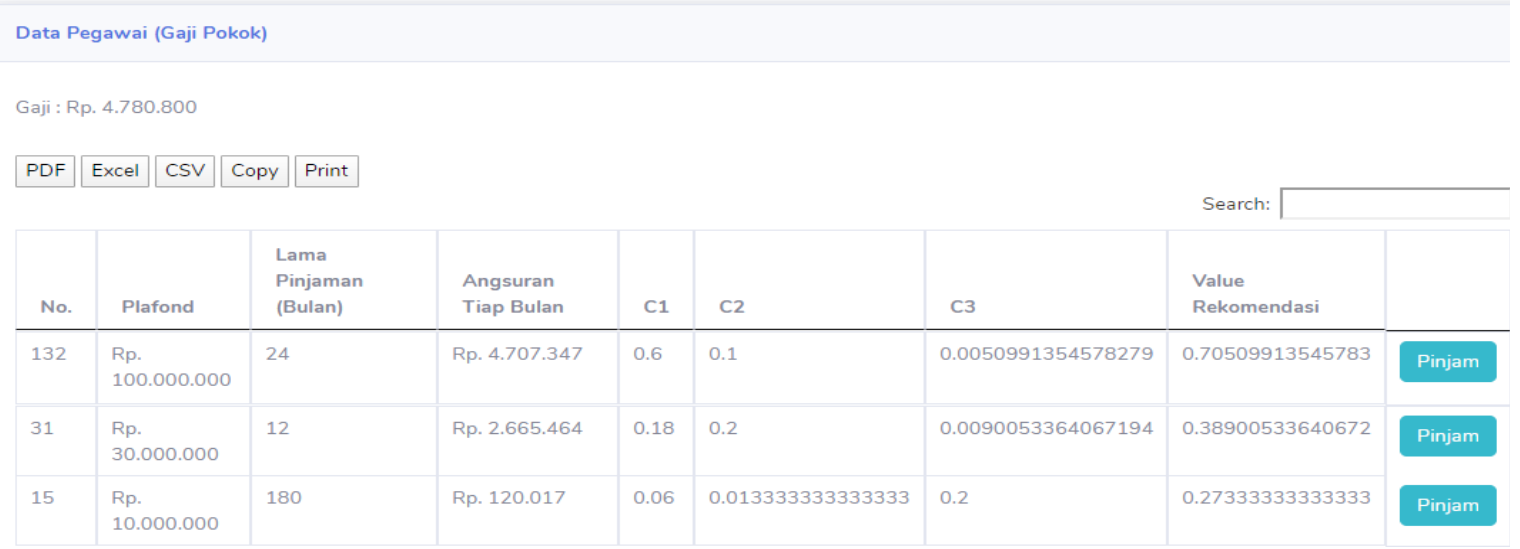

Gambar 13. Matrix Ternormalisasi

\subsubsection{Total Nilai Setiap Alternatif}

Hasil dari gambar 14 ini adalah penjumlahan masing-masing hasil perhitungan $\mathrm{C} 1$, C2, dan C3 pada data nomer 132, 31, dan 15 pada gambar 6 kemudian didapatkan pengurutan hasil rekomendasi pinjaman untuk data nomer 132, 31, dan 15 pada gambar 14 yang berurut dari pinjaman nomer 132, pinjaman nomer 31, dan terkahir pinjaman nomer 15. 


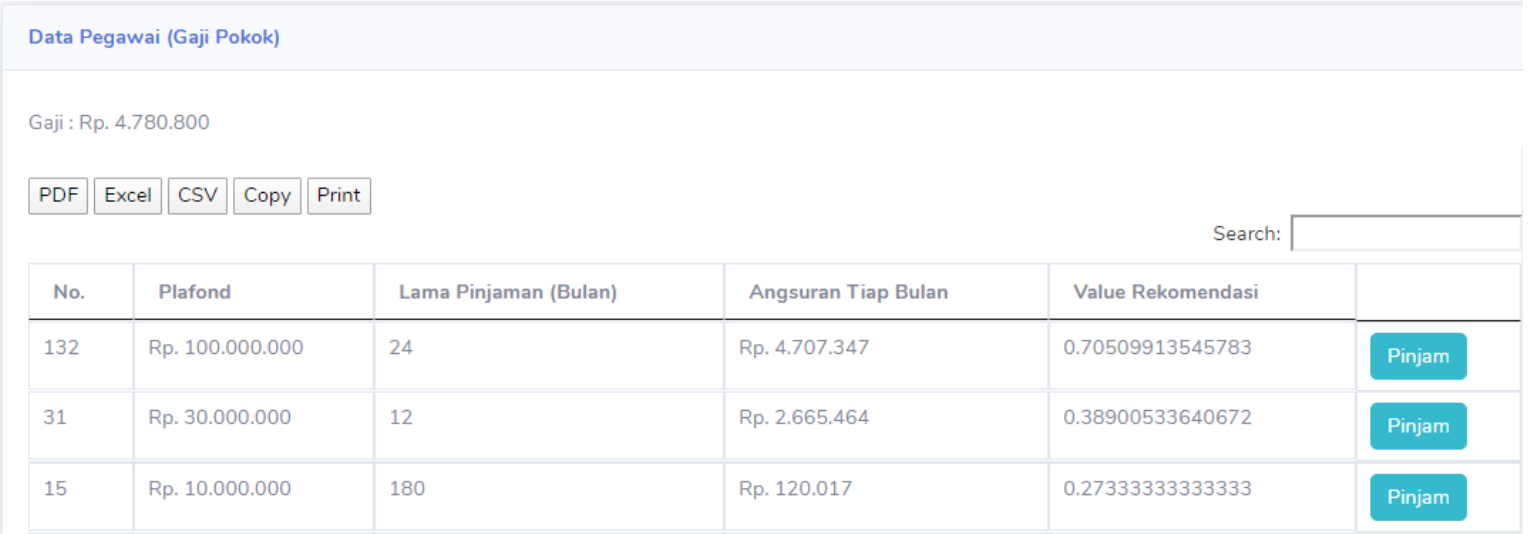

Gambar 14. Total Nilai Setiap Alternatif

\subsection{Evaluasi Metode Simple Additive Weighting}

Dari salah satu sample perhitungan metode SAW pada salah satu pegawai dengan gaji diterima berkisar Rp. 4.780.800, didapatkan hasil akhir perhitungan penentuan rekomendasi pinjaman secara manual pada tabel 6 memiliki hasil serupa dengan perhitungan penentuan rekomendasi pinjaman dengan aplikasi pada gambar 14. Seluruh perhitungan yang ada pun sudah mengikuti rumus yang didapat dari persamaan 1 dan persamaan 2 untuk memunculkan rekomendasi terbaik sesuai dengan urutan kepentingan kriteria pada tabel 2. Dengan Pemberian Rekomendasi ini diharapkan kesalahan mengenai pemberian pinjaman yang tidak sesuai seperti cerita dari pegawai keuangan dapat dihindari.

\section{Kesimpulan}

Aplikasi slip gaji ini dapat mengurangi human error terhadap pengeloaan pinjaman dan pemberian rekomendasi dari daftar pinjaman dengan menggunakan metode SAW. Data yang tersimpan sudah terkomputerisasi. Selain itu seluruh pinjaman yang sudah terdata di dalam aplikasi akan mudah dimonitoring dan dicek karena dapat diperbarui berdasarkan kondisi tertentu. Kemudian tentang penggajian, aplikasi ini berhasil membantu bagian keuangan dalam menyebarkan data penggajian secara langsung melalui email. Hal ini dapat mengurangi penggunaan kertas.

\section{Daftar Pustaka}

[1] Devi Lestari, "Perancangan Sistem Informasi Penggajian Karyawan Pada PR. Tunas Mandiri Kabupaten Pacitan," Indonesian Journal on Networking and Security, vol. 3, no. 4, pp. 22-26, 2014.

[2] Hasan Abdurahman and Asep Ririh R, "Aplikasi Pembayaran Secara Kredit Pada Bank Yudha Bhakti," Jurnal Computech \& Bisnis, vol. 8, no. 2, pp. 61-69, 2014.

[3] Devara Eko Katon Mahardika, "Design and Development of Web Based Employee Payroll Information System Using Codeigniter Framework and Extreme Programming Method," International Journal on Informatics for Development, vol. 7, no. 2, pp.: 1-6.

[4] Dwi Jayanti and Siska Iriani, "Sistem Informasi Penggajian Pada CV. Blumbang Sejati Pacitan", Journal Speed - Sentra Penelitian Engineering dan Edukasi, vol. 6, no. 3, pp. 36-43, 2014. 
[5] Djati Poetryono and Satrio Broto, "Implmentasi Slip Gaji Elektronik Dalam Rangka Menjangkau Lokasi Karyawan Yang Bertugas Di Berbagai Lokasi," Ekonomi Bisnis \& Kewirausahaan, vol. 4, no. 2, pp.69-84, 2015.

[6] Arie Widya Saputra and Imam Bukhori, "Perancangan sistem informasi penggajian Pada Sekolah Menengah pertama(SMP) PGRI Kebonagung," Indonesian Journal on Networking and Security, vol. 3, no. 3, pp. 6-10, 2014.

[7] Cepi Setiawan and Rinawari, "Implementasi Peminjaman dan Pembayaran Angsuran Pada BPR Kabupaten Bandung," Jurnal Computech \&Bisnis, vol. 9, no. 1, pp. 3747, 2015.

[8] Yesni Malau, and Tubagus Aom Somadiningrat D.W.K, "Implementasi Slip Gaji Elektronik Pada Cv Mediaku Kreatif (Motion Production)," Jurnal Swabumi, Vol. 6, No. 1, pp. 8-17, 2018.

[9] A. Adi Putra, D. Andreswari, and B. Susilo, "Sistem Pendukung Keputusan Untuk Penerima Bantuan Pinjaman Samisake Dengan Metode Electre (Studi Kasus: Lkm Kelurahan Lingkar Timur Kota Bengkulu),” Jurnal Rekursif, Vol. 3, No. 1, pp. 1-11, 2015.

[10] M. Nur Faiz, Rusydi Umar, and Anton Yudhana, "Implementasi Live Forensics untuk Perbandingan Browser pada Keamanan Email," Vol. 1, No. 3, pp. 108-114, 2017.

[11] Muhammad Aris, and Mohd Nur Syechalad, "Pengaruh Pola Konsumsi Terhadap Permintaan Kredit Konsumtif Di Banda Aceh," Jurnal Ilmiah Mahasiswa (JIM), Vol. 3, No. 1, pp. 100-109, 2016.

[12] A. Adi Putra, D. Andreswari, and B. Susilo, "Sistem Pendukung Keputusan Untuk Penerima Bantuan Pinjaman Samisake Dengan Metode Electre (Studi Kasus: Lkm Kelurahan Lingkar Timur Kota Bengkulu)," Jurnal Rekursif, Vol. 3, No. 1, pp. 1-11, 2015.

[13] Sri Haryanti, and Tri Irianto, "Rancang Bangun Sistem Informasi E-Commerce Untuk Usaha Fashion Studi Kasus Omah Mode Kudus," Journal Speed - Sentra Penelitian Engineering dan Edukasi, Vol. 3, No. 1, pp. 8-14, 2011.

[14] Agus Perdana Windarto, "Penilaian Prestasi Kerja Karyawan Ptpn Iii Pematangsiantar Dengan Metode Simple Additive Weighting (Saw)," Jurnal Riset Sistem Informasi Dan Teknik Informatika, Vol. 2, No. 1, pp. 84-95, 2017.

[15] F. Nugrahaa, B. Surarsob, and B. Noranitac, "Sistem Pendukung Keputusan Evaluasi Pemilihan Pemenang Pengadaan Aset dengan Metode Simple Additive Weighting (SAW),”Jurnal Sistem Informasi Bisnis, Vol. 2, pp. 67-72, 2012. 